\title{
Ursula von der Leyen - A Rocky Start, But Brighter Prospects
}

Nine votes. That was the margin in the European Parliament (EP) that will bring the nominee of the European Council, Ursula von der Leyen, to succeed Jean-Claude Juncker as President of the European Commission. The vote was preceded by high political drama that attracted unprecedented levels of public attention to issues of governance and legitimacy in the European Union.

A brief recapitulation of the drama starts in 2014 when the EP declared that it would only accept nominations by the European Council of people who had campaigned in the European elections as lead candidates of one of the European political families. The Council duly nominated Spitzenkandidat Juncker, whose centre-right EPP was by a large margin the biggest parliamentary group. Important players on the Council were resentful of this restriction of their prerogatives. Their chance came this year when no clear parliamentary majority emerged in favour of any of the lead candidates. After bruising negotiations in the Council, von der Leyen was nominated out of the blue, as part of a package of top-level positions.

The EP was now in a pickle. Should it make a stand for the Spitzenkandidat principle and vote down the Council's nominee? There was clearly a case for sticking to principle (not to mention that as German defence minister von der Leyen faces a parliamentary enquiry into a substantial misallocation of public funds). However, there were numerous pragmatic reasons for MEPs to accept von der Leyen's nomination. In the end she scraped by with 383 votes - nine votes above the necessary 374 out of 747 MEPs.

As the ballot was secret, the precise composition of her 'supporting coalition' is not clear. The Left, the Greens and the parties to the right of the eurosceptic-conservative ECR group voted against. On paper, a "centrist bloc" consisting of Christian Democrats (182), Social Democrats (154) and Liberals (108) could muster 444 votes. Of these, 61 votes went missing, equivalent to around $40 \%$ of the socialists' tally. The eurosceptic ECR, dominated by Poland's PiS party, trumpeted after the vote that its support for von der Leyen had been decisive. In the case that all ECR MEPs voted in favour of von der Leyen, the number of 'missing' votes among prointegration parties would double. Given that Viktor Orban's Fidesz MEPs - affiliated formally with the EPP but ideologically closer to the ECR, if not to the new far-right group (ID) - also declared that they had voted for the Council nominee, commentators claimed that the new Commission President-elect is fatally compromised and a prisoner of the eurosceptics. This verdict is not justified, however, regardless of the manner in which von der Leyen was elected, 'what might have been' if the EP and the Council had acted more cooperatively, or of her ministerial record.

One reason is a simple and formal one. Ursula von der Leyen is now elected and would have been with a one-vote majority. The EP has shot its bolt, until it has to approve the entire Commission in October. Whether or not she achieves the necessary majorities for her proposals on the Commission, the Council and the EP during her five-year term is not determined by the size or composition of the majority that confirmed her nomination on 16 July. PiS and Fidesz can, of course, as governing parties exert influence through their nomination of commissioners and in Council votes. But Commission nominations will be sorted out soon and are then fixed. On the Council, Poland and Hungary - even allied with Italy - are far from a blocking minority. In short, there is no clear basis for these parties who voted for von der Leyen to believe that they will have any additional leverage over her beyond what they already enjoy as representatives of a medium-sized and a small EU country. Both rely on EU funds for their current economic growth to a considerable degree. Just saying. 
Meanwhile, despite all the talk of a populist, Eurosceptic surge, there is a clear majority for prointegration policies in the EP (albeit with some variation in composition according to topic). This brings us to von der Leyen's speech to the EP and the 'agenda'1 she published shortly before the vote. One of the great ironies of the whole process was that the substance of her speech and agenda was broadly welcomed by left-of-centre forces - many of whom voted against her - but was criticised by right-of-centre eurosceptic forces who voted for her. Unpicking exactly how that ironic result came about would require a detailed party-by-party analysis. But the crucial point is that - whatever telephone calls were made between Berlin, Warsaw and Budapest - von der Leyen had set out a substantive vision that was clearly aimed at winning over pro-integration forces. In fact, I would argue that, if the commitments are taken at face value, the agenda is the most internationalist-progressive agenda that has been set out at EU level in many years.

Sceptical? Consider commitments in three priority areas that comprise her agenda: Under "A European Green Deal", her implicit first priority, the commitments include giving the 2050 climate neutrality goal legal force and (some) extension of the Emissions Trading System (ETS) and a border adjustment tax; the goal of doubling the proportion of European Investment Bank lending going to climate-related projects; and (vague) funding promises for just transition and on biodiversity. There is nothing not to like here for the Greens (and ecologically motivated MEPs in other groups).

Under "An economy that works for people", von der Leyen proposes a legal instrument to provide a 'fair' minimum wage for every worker in the EU (a key campaign proposal of S\&D lead candidate Frans Timmermans); a European Unemployment Benefit Reinsurance Scheme (repeatedly rejected during the election campaign by EPP lead candidate Manfred Weber); (limited) deepening of the EMU, notably a commitment to a European Deposit Insurance Scheme, bitterly opposed in her home country; and a promise to implement an EU digital tax if a global solution cannot be found by the end of 2020 . She also made substantial commitments in the area of gender equality (pay transparency rules and, not least, a gender balanced EU Commission). There is nothing not to like here for social-democrats (and social liberals and parts of the left group).

Jumping to the last pillar, "A new push for European democracy", von der Leyen reiterated promises made by various lead candidates to respond to a request for legislation from a majority in the EP. A full right of legislative initiative, which she supports in principle, would require Treaty change. Recognising the rancor caused by the interinstitutional conflict underlying her nomination, she promised to seek an agreed basis for implementing something like the Spitzenkandidat principle including taking a favourable attitude to transnational lists for the next EP election, which her political family voted down in the last legislature. This is an important concession to all those MEPs who voted against her on principle because she was not a lead candidate.

Although some may dismiss it as a lot of warm and fuzzy words, the measures I have listed from the agenda take the form of clear commitments. Of course this does not mean that all of them will see the legislative light of day by the end of the Commission's five-year mandate. All elements require the assent of a majority in the EP and a qualified majority (occasionally unanimity) in the Council. The Commission President-elect is doubtless aware that the Council currently represents a choke point for a number of these proposals. The point is that the agenda represents a written commitment by the President-elect to which pro-integration forces in the EP, who together have a clear majority, can hold the incoming Commission.

Andrew Watt, The Macroeconomic Policy Institute (IMK), Dusseldorf, Germany.
The next step and von der Leyen's first test is the formation of the Commission, based on Member State nominations. Her proposal requires the endorsement of the EP. My prediction: The coalition supporting the Commission as a whole in autumn will be considerably larger and different in composition than that which narrowly voted for Ursula von der Leyen in July.

1 U. von der Leyen: A Union that strives for more. My agenda for Europe, 16 July 2019, available at https:// ec.europa.eu/commission/sites/beta-political/files/political-guidelines-next-commission_en.pdf. 